\title{
透析看護者のストレス要因と光の対処法・解消法について
}

\author{
愛 敬 恭子 酒 井 孝子* 吉福 美和子* 松隈 玄一郎* \\ 笹川佳子** 船越 衛—**
}

長崎市医師会看護専門学校 衆和会桜町病院* 同クリニック**

key words: Burn out, 対人的要因, 対処機制, 不健康な防衛機制, 外向的解消法

〈要旨〉

透析看護者のストレス要因と午の対処法・解消法についてアンケート調査を行い検討した．有効回答者は 171 名(35 施設)であった. 稲岡ら ${ }^{1)}$ の算定法に基づいて Burn out スコアを算定したところ, Burn out に陥っている比率は $24.5 \%$ であり，透析室勤務はICU, 手術室勤務と同様, ストレスの高い職場であることが考えられた。

Burn out に導く要因を明確にするため, 各回答項目と健全群, Burn out 群間で $\chi^{2}$ 検定を行った。 その結果, 有意 水準 $1 \%$ で有意差がみられた心理的要因 5 項目, 対人的要因 5 項目, 物理的要因 2 項目, 社会的要因 6 項目, 個人的 要因 6 項目の計 24 項目が, Burn out に導く要因となることが明らかになった.

また，健全群と Burn out 群のストレス対処法および解消法には違いがみられた。健全群はストレス対処法として, 「あせらず優先される仕事から片づける」が最も多く, 次いで「スタッフと共に考える」等, 積極的に問題解決に取り 組む対処機制であった。

それに対し Burn out 群は，「他人と争うよりも妥協する」が最も多く，次いで「自分自身の内部で克服する」「何 事も過大に期待しないようにする」等, 不健康な防衛機制に該当する逃避傾向にある者に多くみられた。

ストレス解消法について, 健全群は外向的解消法であり, ストレスをうまく昇華しているが, Burn out 群は内向的 解消法が主であった。

透析看護者が Burn out に陥らないために, 外向的解消法が必要と思われた。

\section{Causes of stress among dialysis nursing staff and methods of coping with and relieving such stress}

Kyoko Aikyo, Takako Sakai*, Miwako Yoshifuku*, Genichiro Matsukuma*, Yoshiko Sasagawa**, Morikazu Funakoshi**

Nagasakishi Ishikai Kango Speciality School ; Syuwakai Sakuramachi Hospital* ; Sakuramachi Clinic**

We developed a questionnaire on conditions of stress in dialysis nursing staff and on their methods of coping with and relieving such stress.

Valid answers were received from 171 nursing staff members at 35 different institutions.

When computing the burn-out score by the Inaoka method, it was found that $24.5 \%$ of the staff had reached burn-out level in a dialysis ward, indicating that the environment is as high stress as that of the ICU and the operation theatre.

To clarify the factors leading to burn-out, the subjects of each reply were divided into a "healthy" (normal group) and a burn-out group and were then examined by the $\chi^{2}$ method. As a result, it became clear that, at a consciousness level of $1 \%$, the differences in interpretation of 5 psychological, 5 personality, 2 physical, 6 social and 6 personal subjects (a total of 24 in all), emerged as factors leading to burn-out.

Moreover, differences could be seen between the "healthy" group and the burn-out group in their respective ways of coping with and relieving stress.

\footnotetext{
酒井 孝子 衆和会桜町病院テ 850 長崎市ダイアランド 2-40-1 (0958-79-3339)
} 
A majority of the "healthy" group coped with stress by "disposing of work in order of precedence (importance) in an unhurried manner" ; the next most prevalent method was "thinking things over with other staff members" ; in other words a method of solving problems in a positive way.

On the other hand, the burn-out group's method vas "by compromise rather then confrontation"' ; next came "overcoming problems within oneself" and "not having too great expectations about anything". Thus, many in this group had a tendency to resort to "unhealthy prevention methods" which amounted to avoidance of the problems involved.

Regarding relief of stress, whereas the healthy group sublimate their stress by indulging in extroverted methods of relief, the burn-out group resorted mainly to introverted methods.

It appears, therefore, that extroverted methods of stress relief are a necessity in preventing burn-out among dialysis nursing staff.

\section{緒言}

近年，透析医療の技術の進歩に伴い，単なる延命から “quality of life” が追求されるようになってきた。透析 医療に従事する看護者は高度な医学的知識，熟達した技 術とともに心理的，社会的ニードを満たすケア意欲が要 求されている.

しかも, これらは患者の全生涯を通じて繰り返される エンドレスケアである。看護者のストレス ${ }^{2)}$ ははかりし れず，ケア意欲に影響を与えているのではないかと考え られる。

今回私たちは，アンケート調査により今までに研究さ れていない透析医療に従事する看護者のケア意欲の程度 およびその意欲を左右する要因とストレス対処法につい て検討したので報告する。

\section{方法}

\section{1. 調查対象および方法}

透析医療に従事する看護者 300 名（45 施設）を血液透 析施設名簿から無作為に抽出し，アンケートを直接郵送 し，無記名方式で実施した。

2. 調查期間

1989 年 6 月 1 日 6 月 30 日

3. 調查内容

1) 背景因子

性, 年歯, 婚姻, 職位, 資格, 経験年数, 通勤方法と 所要時間, 住宅状況

2 ) Burn out 程度の測定

3) Burn out に導々要因

心理的, 対人的, 物理的, 社会的, 職場要因および個 人的要因
4 ）透析看護について（記述式）
(1)現在の勤務場所の選択とその理由
(2)透析看護を続けたいか否かとその理由
5 ) 欲求不満, 緊張, ストレス解消について
4. 分析方法

Burn out 測定に関しては稲岡らの算定法に基づいて Burn out スコアを算定した。

健全群スコア 2.9 以下……精神的に安定し，心身共 に健全である。

警戒群スコア $3.0 \sim 3.9 \cdots \cdots$ Burn out の徵候がみら れる

Burn out 群スコア 4.0 以上……Burn out に陥って いる。

以上の 3 群に分類した。各種要因については $\chi^{2}$ 検定 にしたがって統計学的分析を行った。

\section{結果}

アンケート配布数 300 名（45 施設）郵送方式による無 記名であるが，本調查に協力して回答したものは，179 名，そのうち有効回答者は 171 名 $(57 \%) 35$ 施設である. 所定の算定方法に基づいて 3 群に区分したところ健全群 に含まれるものは 61 名(35.7\%)であり，警戒群は 68 名 (39.8\%)，Burn out 群は 42 名 $(24.5 \%)$ であった。全 対象者のスコアの平均值は 3.4 , 最低スコア 1.57 , 最高 スコアは 6.81 であった。

1. Burn out と背景因子との関係

1 ) 年齢との関係は, 30 歳代が $33.8 \%$ と最も多く, つ いで 50 歳代 $33.3 \%$ あり 20 歳代が $16 \%$ と最も少な かった（表 1 参照)。

2 ）婚姻との関係では未婚者の $26.3 \%$ ，既婚者の $23.7 \%$ Burn out であった。

3 ）職位との関係は，婦長の $37.5 \%$ ，主任の $26.1 \%$, スタッフ看護婦の $23.6 \%$ Burn out であった。

4 ）現在の勤務場所での経験年数との関係では 21 年 以上が 2 人中 2 人とも $100 \%$ Burn out であり，16〜20 年が 5 人中 3 人の $60 \%$, 次いで 11〜 15 年が $29.6 \%, 5$ 年以下が $19.7 \%$ と最も少なかった（表 2 参照）。

5 ）通勤時間との関係では， 1 時間以上が 14 人中 5 人 の $35.7 \%$ Burn out であった。

6 ）施設規模との関係では専門病院勤務者 $41.8 \%$, 総 
表 1 Burn out と年齢の関係

\begin{tabular}{|c|c|c|c|c|c|c|c|}
\hline $\begin{array}{l}\text { 年齢 } \\
\text { Burn } \\
\text { out } 9 \text { 程度 }\end{array}$ & 計 & $21 \sim 30$ 歳 & $31 \sim 40$ 歳 & $41 \sim 50$ 歳 & $51 \sim 60$ 歳 & 60 歳以上 & 無回答 \\
\hline 計 & $171(100.0)$ & $75(100.0)$ & $74(100.0)$ & $15(100.0)$ & $3(100.0)$ & & $4(100.0)$ \\
\hline 健全群 & $61(35.7)$ & $33(44.0)$ & $22(29.7)$ & $5(33.3)$ & 0( & 0( & $1(25.0)$ \\
\hline 警戒群 & $68(39.8)$ & $30(40.0)$ & $27(36.5)$ & $7(46.7)$ & $2(66.7)$ & 0( & $2(50.0)$ \\
\hline Burn out 群 & $42(24.5)$ & $12(16.0)$ & $25(33.8)$ & $3(20.2)$ & $1(33.3)$ & 0( & $1(25.0)$ \\
\hline
\end{tabular}

表 2 Burn out と透析勤務年数との関係

\begin{tabular}{|c|c|c|c|c|c|c|c|}
\hline $\begin{array}{l}\text { 勤務年数 } \\
\text { Burn } \\
\text { out } の \text { 程度 }\end{array}$ & 計 & 5 年以下 & $5 \sim 10$ 年 & $11 \sim 15$ 年 & $16 \sim 20$ 年 & 21 年以上 & 無 回答 \\
\hline 計 & $171(100.0)$ & $76(100.0)$ & $59(100.0)$ & $27(100.0)$ & $5(100.0)$ & $2(100.0)$ & $2(100.0)$ \\
\hline 健全群 & $61(35.7)$ & $24(31.6)$ & $29(49.2)$ & $5(18.5)$ & $2(40.0)$ & 0( & $1(50.0)$ \\
\hline 警戒群 & $68(39.8)$ & $37(48.7)$ & $16(27.1)$ & $14(51.9)$ & $0\left(\begin{array}{ll}0 & 0\end{array}\right)$ & $0\left(\begin{array}{ll}0 & 0\end{array}\right)$ & $1(50.0)$ \\
\hline Burn out 群 & $42(24.5)$ & $15(19.7)$ & $14(23.7)$ & $8(29.6)$ & $3(60.0)$ & $2(100.0)$ & $0\left(\begin{array}{ll}0 & 0\end{array}\right)$ \\
\hline
\end{tabular}

合病院勤務者 $24.4 \%$ が Burn out であるのに対し, 診療 所では 37 名中 Burn out の者は 0 名であった.

以上述べた背景因子の中で有意差があった者は施設規 模との関係で $\chi^{2}=24.85 \mathrm{p}<0.01$ で有意差がみられた (表 3 参照).

\section{Burn out に導く要因}

心理的, 対人的, 物理的, 社会的職場環境, 個人的要 因について, 各回答と Burn out の程度との関係（健全 群，警戒群，Burn out 群）を調べてみた。

Burn out に導く要因を明確にするため, 各回答項目と 健全群, Burn out 群間で $\chi^{2}$ 検定を行い, Burn out の 関連性を調べた。 $\chi^{2}$ 検定の結果, 有意水準 $1 \%$ で有意差 がみられた項目は心理的要因 5 項目, 対人的要因 5 項目, 物理的要因 2 項目, 社会的要因 6 項目, 個人的要因 6 項 目の計 24 項目が Burn out に導く要因となり得ること が明らかになった。そこで各要因別にみると，

\section{1 ）心理的職場要因}

【現在の仕事は精神的に負担である】と思っている人 は健全群では $35.5 \%$, Burn out 群は $66.6 \%$ を占めた。 【職場には, はつらつとして働く需囲気がある】と思って いる人は, 健全群では $46.5 \%$, Burn out 群では $0 \%$ で ある.【職場では仕事上の悩み問題を気軽に話し合える雾 囲気がある】と思っている人は健全群では $62 \%$, Burn out 群では $16.7 \%$ あ゙る。 $\chi^{2}$ 検定では【職場では，はつ らつとして働く䨌囲気がある, ない】が 33.18 と最も多 かった。

\section{2 ) 対人的要因}

【スタッフ同士の交流を通し慰めあったり,不満をぶっ つけあったり，励ましあったりしている】と思っている
表 3 Burn out と施設規模との関係

\begin{tabular}{c|r|c|c|c}
\hline $\begin{array}{c}\text { 施設規模 } \\
\begin{array}{c}\text { Burn } \\
\text { out の程度 }\end{array}\end{array}$ & 計 & 総合病院 & 専門病院 & 診療所 \\
\hline 計 & $171(100.0)$ & $78(100.0)$ & $55(100.0)$ & $37(100.0)$ \\
健全群 & $61(35.7)$ & $30(38.4)$ & $10(18.2)$ & $21(56.8)$ \\
警戒群 & $68(39.8)$ & $29(37.2)$ & $22(40.0)$ & $16(43.2)$ \\
Burn out 群 & $42(24.5)$ & $19(24.4)$ & $23(41.8)$ & $0\left(\begin{array}{l}0 \\
\text { Burn }\end{array}\right.$ \\
\hline
\end{tabular}

人は健全群 $72.1 \%$, Burn out 群 $32.8 \%$ でる.【職場で のミーティングでは自由に考呈意見が交換される】と 思っている人は健全群 $52.4 \%$, Burn out 群 $28.5 \%$ であ る.【看護チームとしてチームワークがとれている】と 思っている人は健全群 $57.3 \%$, Burn out 群は $16.6 \%$ で あった～$\chi^{2}$ 検定では【職場でのミーティングでは自由に 考えや意見が交換される，されない】が 20.19 と最も高 かった。

\section{3 ) 物理的要因}

【あなたは定められた休憩時間をとっている】と思っ ている人は健全群 $80.4 \%$, Burn out 群は $57.1 \%$ あるる。 【現在の処遇, 待遇に満足している】と思っている人は健 全群 $18 \%$, Burn out 群 $7.1 \%$ である. $\chi^{2}$ 検定では【現 在の処遇, 待遇に満足している, いない】が 17.41 と最 も高かった。

4 ) 社会的要因

【現在の職場は看護者が不足している】と思っている 人は, 健全群 $63.8 \%$, Burn out 群は $90.4 \%$ でる.【現 在の仕事は仕事量が多すぎる】と思っている人は健全群 $39.2 \%$ ，Burn out 群は 73.7\%である.【自分の行ってい るケアの効果について疑問あるいは無力感をもつ】と 


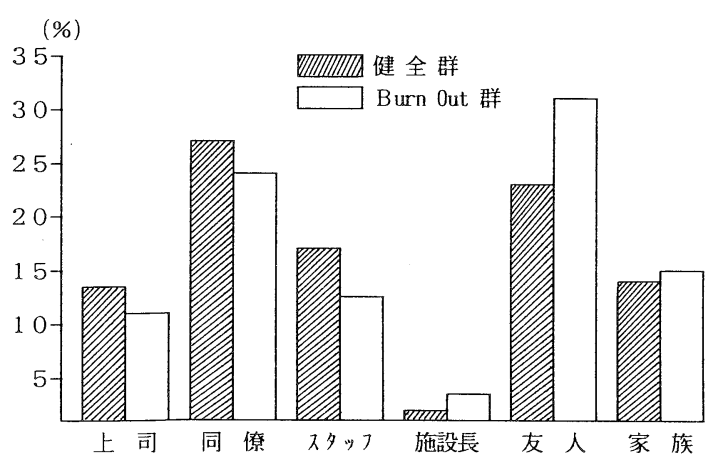

図 1 Burn out 群と相談者の関係（延べ数）

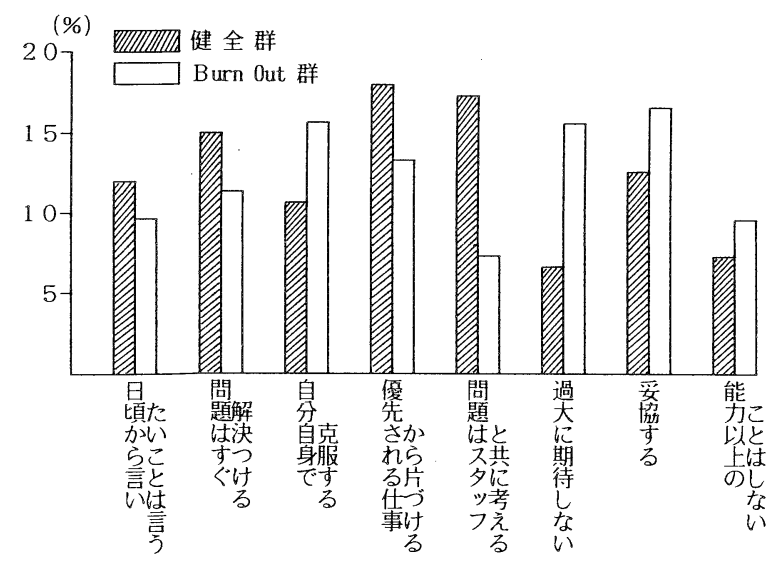

図 2 Burn out 群とストレス対処法の関係（延べ数）

思っている人は，健全群 $37.2 \%$, Burn out 群 $69.1 \%$ で ある、【毎月の勤務希望がかなえられる】と思っている人 は健全群 $81.9 \%$, Burn out 群 40.5\%である。秋検定で は【毎月の勤務希望はかなえられる，かなえられない】 が 47.53 と最も高かった。

\section{5 ) 個人的要因}

【現在の仕事は私生活や家族に悪い影響を及ぼしてい る】と思っている人は, 健全群 $17.9 \%$, Burn out 群 42.9\%である。【私的生活を楽しんでいる】と思っている 人は, 健全群 $59 \%$, Burn out 群 $28.6 \%$ である.【現在何 らかの病気で悩まされている】と思っている人は健全群 $13.1 \%$ ，Burn out 群 $42.8 \%$ である。 $\chi^{2}$ 検定では【現在 の仕事は私生活や家族に悪い影響を及ほしている，いな い】が 19.96 と最も高かった。さらに有意差のみられた 24 項目の中で相対危険度 2.9 以上 10 項目を Burn out に導く強力な要因として抽出した。 [心理的要因]

(1)職場では仕事上の悩み，問題を気軽に話し合える䨌 囲気がある，ない $(\gamma \cdot \gamma=3.9)$
(2)職場での自分の存在価值が認められている，いない

$$
(\gamma \cdot \gamma=2.9)
$$

(3)職場では看護活動の目標達成に意欲的である, ない

$$
(\gamma \cdot \gamma=2.9)
$$

[対人的要因]

(4)スタッフ同士の交流を通し慰めあったり，不満を ぶっつけあったりしている，いない

$$
(\gamma \cdot \gamma=2.9)
$$

(5)看護チームとしてチームワークがとれている，いな ()

$$
(\gamma \cdot \gamma=3.7)
$$

〔社会的要因〕

6)現在の職場は看護婦が不足している，いない

$$
(\gamma \cdot \gamma=7.0)
$$

(7)現在の職場は仕事量が多すぎる，多すぎない

$$
(\gamma \cdot \gamma=6.2)
$$

(8)毎月の勤務希望はかなえられる，かなえられない

$$
(\gamma \cdot \gamma=3.2)
$$

〔個人的要因〕

(9)現在の仕事は私生活や家族に悪い影響を及ぼしてい

$$
\text { る,いない }(\dot{\gamma} \cdot \gamma=3.3)
$$

(10)私的生活を楽しんでいる，いない

$$
(\gamma \cdot \gamma=3.0)
$$

物理的要因は 10 項目に入っていない.

3 . 透析看護について（自由記述式）

現在の勤務場所との関係は, 本人の希望で透析室配置 になった人の $44.9 \%$ が健全群で，19.2\%が Burn out 群 であった。本人の希望に反し，透析室へ配置転換させら れた人の中で $30.4 \%$ が Burn out 群である。透析看護を 続けたいかの問に対して, 続けたいと答えた人の中で $38.8 \%$ が健全群で，15.3\%が Burn out 群である。

4. 欲求不満, 緊張, ストレス解消について

1 ）仕事上の行きづまり，悩みを誰に相談するか（図 1 参照) の質問に対して, 健全群は同僚が, Burn out 群 は友人が 1 位だった。施設長，母校の教師に相談するも のは健全群，Burn out 群ともに非常に少なかった。

回答が多い項目の順位は, 健全群一 1 位同僚, 2 位友 人, 3 位スタッフ, 4 位家族, 5 位上司. Burn out 群一 1 位友人， 2 位同僚，3 位家族，4 位スタッフ，5 位上司 である。

2 ) 仕事と関連しておこってくる葛藤, 欲求不満, 緊 張，ストレスなどについて，あなたはその対処のしかた としてどのような考え方をもっているか（図 2 参照）の 質問に対して健全群で回答が多い項目は,

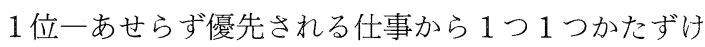
る $(17.8 \%)$

2 位一問題がおきれば時間をかけ，必要ならばス夕ッ 
表 4 ストレス予防法・解消法のアンケート項目

\begin{tabular}{|c|c|}
\hline 1. 信頼している人に話しを聞いてもらう & 14. 思いきり泣く \\
\hline 2. 趣味に打ち込む & 15. 美味しいものを食べる \\
\hline 3.テレビをみる & 16. 賭け事をする \\
\hline 4.スポーツ，レクリェーションに参加する & 17. じっとたえる \\
\hline 5. ボランティア活動に参加する & 18.ヒステリーをおこす \\
\hline 6.アルコールを飲む & 19. 寡黙になる \\
\hline 7. 旅行する & 20. 悩みを書きつづる \\
\hline 8・ふてねをする & 21. 座禅とか自己訓練をする \\
\hline 9、精神安定剂を服用する & 22. 好みの本を読む \\
\hline 10. 衝動買いする & 23.人にあたる \\
\hline 11. 宗教活動をする & 24.職場以外で看護活動をする \\
\hline 12. 空想にふける & 25. その他 \\
\hline 13. 電話で友人と長話をする & \\
\hline
\end{tabular}

フと共にその解決方法について考える $(17.3 \%)$ 3 位一問題がおきれば，すぐその場所で解決をつける ようにする $(14.9 \%)$

であり，回答の中で一番少なかった項目は，何事も過大 に期待しないようにするであった。

Burn out 群で回答が多い項目は,

1 位一他人と争うよりも妥協する（17.1\%）

2 位一何事も過大に期待しないようにする，自分自身 の内部で克服する（15.4\%）

であり，回答の中で一番少なかった項目は，問題がおき れば時間をかけ，必要ならばスタッフと共にその理解方 法について考えるであった。

3) 2)の対処法の問題と関連して, あなたは具体的 にどのように予防し解消しようとしているかの質問に対 して,

健全群で回答が多い項目は,

1 位一信頼している人にじっくりと話を聞いてもらう $(20.2 \%)$

2 位一美味しいものを食べる（8.7\%）

3 位一趣味（映画，観劇，コンサート等）に打ち込む (7.7\%) である.

Burn out 群で回答が多い項目は,

1 位一信頼している人にじっくりと話を聞いてもらう $(15.3 \%)$

2 位一電話で友人と長話をする（10.2\%）

3 位一アルコールを飲む $(9.2 \%)$ であった，健全群，

Burn out 群ともに回答が $2 \%$ 以下は，25 項目 （表 4 参照）中 8 項目である.

それはボランティア活動に参加する，精神安定剂を服 用する, 宗教活動をする, 賭け事をする, 職場以外で看 護活動をする，悩みを書きつづる，座禅とか自己訓練を する，その他等々である。

\section{考察}

調査対象者の平均スコアは 3.43, Burn out に陥って いる人は $24.5 \%$ あった。これは斉藤ら ${ }^{3)}$ の研究による, ICU の平均スコア 3.47 , Burn out に陥っている人 $25.2 \%$ に比べるとやや低いが，それでも看護婦の約 $1 / 4$ が Burn out に陷っていることになる。

松田ら ${ }^{4)}$ の研究によると, 平均スコア ICU 3.95, 手術 室で 3.46 である。れと比べると, 本研究の 3.43 は ICUより低いが手術室とほぼ同値である。これは透析室 勤務が ICU, 手術室勤務と同様ストレスの高い職場5)で あるといえる。

Burn outに陥っている人は 30 歳代で現在の勤務場所 での経験年数 $11 \sim 15$ 年の看護者, 希望に反し透析室へ配 置転換させられた看護者, 透析専門病院の看護者などに ケア意欲が喪失している比率が高くみられた。

これは, 透析看護が患者の全生涯を通して繰り返され るエンドレスケアであるため, 看護者としての達成感の 喜びが得られにくいこと, 複雑多様な問題をかかえてい る透析患者との人間関係の困難さ, 特に長期透析患者の 心理的ケアの困難(6)さなどがケア意欲を低下させている のではないかと考えられる。

また毎日の単調な業務の中にも, 器械的操作が多く過 度の緊張感が要求されると共に透析室という閉鎖された ワンフロアの労働環境 ${ }^{7}$ も Burn out の要因として考え られる，その他，看護者としてこのままでは他科の看護 ができなくなるのではという不安もあり，そのことがケ ア意欲に関与しているのではないかとも考えられる。

仕事上の行きづまり, 悩みを相談する相手は, 健全群 では同僚が 1 位であり, スタッフが 3 位であるのに対し， Burn out 群では友人が 1 位, 同僚が 2 位, 家族が 3 位で あった。

このことは Burn out に導く心理的要因である【職場 では仕事上の悩み問題を気軽に話し合える雲囲気があ 
る】と思っている人が健全群では $62 \%$ に対し, Burn out 群では $16.7 \%$ と低かったことに関連していると考えら れる。

ストレス対処法について，健全群は，あせらず優先さ れる仕事から片付けるが最も多く，次いでスタッフと共 に考えるなど, 積極的に問題解決に取り組む, 対処機制 であるのに対し, Burn out 群は他人と争うよりも妥協す るが最も多く，次いで自分自身の内部で克服する，何事 も過大に期待しないようにするなど，不健康な防衛機 制8) に該当する逃避傾向にあった。

ストレスの予防法, 解消法について, 健全群は外向的 解消法であり，ストレスをうまく昇華している，Burn out 群は内向的解消法であり, これは Burn out 群に導 〈個人的要因である【私的生活を楽しんでいる】と思っ ている人は健全群で $59 \%$ ，Burn out 群 $28.6 \%$ であり，

【現在の仕事は私生活や家族に悪い影響を及济している】 が個人的要因の中で一番高く有意差がみられたことも関 連していると考光られる。

以上のことから透析看護者が Burn out に陥らないた めには，仕事上の悩みを気軽に話し合える職場の雾囲気 作り ${ }^{9)}$ と, 外向的解消法である旅行, スポーツ大会, レク リェーション等の施設ぐるみの対策 ${ }^{10)}$ が必要と思われ る.

当院では，職員の心身の健康を図るために週休 2 日制 を導入し，茶道や生花教室を実施しているが，今後も検 討して行く必要がある。

\section{結語}

透析看護者のストレス要因とその対処法, 解消法につ いて研究した。

1。ケア意欲を喪失している看護者は全対象者の $24.5 \%$ あ゙あ.

2、ケア意欲を左右するのは, 個々患者の複雑, 多様 な問題への援助, 患者との人間関係の維持などに代表さ れる心理的, 対人的要因が主であった。
3.ストレス対処法として健全群は対処機制であるの に対し, Burn out 群は不健康な防衛機制に該当する逃避 傾向にある者が多くみられた。

4.ストレス解消法として健全群は外向的に，Burn out 群は内向的に処理している者が主であった。

\section{文献}

1）稲岡文昭，松野かほる，宮里和子：看護職にみられ る Burn out とその要因に関する研究。看護 36 : 81-104, 1984

2）猪下 光：看護職のバーンアウト現象とその発生要 因に関する文献研究。看護展望 $7 ： 14-15 ， 1986$

3）斉藤千里, 稲岡文昭：ICU の職場環境と看護婦の健 康状態の関連についての検討.第 16 回日本看護学会 集録（看護管理）：20-23, 日本看護協会出版会, 東 京, 1985

4）松田久美子：看護者の Burn out とエコグラムに示 される個人特性との関連。看護研究 $21: 61-68,1988$

5）末永姿子, 中谷茂子, 田辺治子：救急医療污打る 職場環境を考える。第 19 回日本看護学会集録(看護 管理）：237-239, 日本看護協会出版会，東京， 1988

6）水附裕子, 東郷登与子, 田中博英：長期透析患者の 看護。臨床透析 6 :81-86, 1990

7）伊藤千賀子，中山富子：透析医療の場に扔ける人間 関係. 臨牀透析 $8: 1279-1284,1990$

8）金子 光：系統看護学講座.成人看護学 $1: 47-53$, 医学書院，東京，1990

9）加藤正明：職場に抢ける精神衛生. 教育と医学 3 : 212-225，1981

10）佐藤昭枝, 宮川愛子, 鶴岡里子, 橋本節美, 長島紀 以, 粐木正子, 徳丸孝子: 職場汿ける精神衛生面 の健康管理を考える. 第 18 回日本看護学会集録 (看 護管理)：24-26, 日本看護協会出版会, 東京, 1987 